
\title{
25 Research Sourere \\ Building a synthesis of economic costs of biological invasions in New Zealand
}

\section{Thomas W. Bodey}

University of Aberdeen https://orcid.org/0000-0002-5334-9615

\section{Zachary T. Carter ( $\square$ zach.carter@auckland.ac.nz )}

University of Auckland https://orcid.org/0000-0002-0709-4412

\section{Phillip J. Haubrock}

Senckenberg Research Institute and Natural History Museum Frankfurt https://orcid.org/0000-00032154-4341

\section{Ross N. Cuthbert}

Queen's University Belfast https://orcid.org/0000-0003-2770-254X

\section{Melissa J. Welsh}

Scion https://orcid.org/0000-0002-0635-4294

\section{Christophe Diagne}

Université Paris-Saclay https://orcid.org/0000-0002-6406-1270

\section{Franck Courchamp}

Université Paris-Saclay https://orcid.org/0000-0001-7605-4548

\section{Research Article}

Keywords: biosecurity, eradication, invasive alien species, InvaCost, island, monetary impacts, resource damages and losses, socioeconomic sectors

Posted Date: January 12th, 2022

DOI: https://doi.org/10.21203/rs.3.rs-1244386/v1

License: (1) (1) This work is licensed under a Creative Commons Attribution 4.0 International License.

Read Full License 


\section{Abstract}

Biological invasions are a major component of anthropogenic environmental change, incurring substantial economic costs across all sectors of society and ecosystems. However, the economic costs of invasions have been disparately reported, lacking synthesis across taxonomic and sectorial scales. Using the newly compiled InvaCost database, we analyse reported economic damage and management costs incurred by biological invasions in New Zealand - a country renowned for its approaches to invasive species management - from 1968 to 2020. In total, US\$69 billion (NZ\$97 billion) is currently reported over this $\sim 50$ year period, with approximately US\$9 billion of this considered highly reliable, observed (c.f. projected) costs. Most (82\%) of these observed economic costs are associated with damage, with comparatively little invested in management (18\%). Reported costs are increasing over time, with damage averaging US\$120 million per year and exceeding management expenditure in all decades. Where specified, most reported costs are from terrestrial plants and animals, with damages most often borne by primary industries such as agriculture and forestry. Management costs are associated more with interventions by authorities and stakeholders. However, some known ecologically (c.f. economically) impactful invasive species are notably absent from estimated damage costs, and management costs are not reported for a number of game animals and agricultural pathogens. Given these gaps for known and potentially damaging invaders, we urge improved cost reporting at the national scale, including improving public accessibility through increased access and digitisation of records, particularly in overlooked socioeconomic sectors and habitats. This also further highlights the importance of investment in management to curtail future damages across all sectors.

\section{Introduction}

Biological invasions are a major component of anthropogenic global change, causing significant disruption to ecosystems across regions, habitat types and taxonomic groups (Bellard et al. 2016; Essl et al. 2020). Across taxa, the rates of biological invasion continue to increase at the global scale (Seebens et al. 2017, 2020), with impacts that challenge conservation efforts, management interventions and socioeconomic enterprises (Hulme et al. 2009; Early et al., 2016). Such impacts are most visible on islands where high levels of endemism, naïveté, elevated introduction rates, and often limited economic capacity to respond, mean invaders can have substantial impacts (Courchamp et al. 2003, Bellard et al. 2017, Russell et al. 2017, Anton et al. 2020). The determination of ecological impacts of invasive alien species has progressed considerably in recent decades, with means of predicting impacts on native communities (Dick et al. 2017) and potential new invaders (Fournier et al. 2019), across multiple scales. However, despite widely known ecological impacts (but see Crystal-Ornelas and Lockwood 2020), effects of biological invasions on socioeconomic sectors such as human health, fisheries or agriculture have lacked synthesis (Paini et al. 2016; Shackleton et al., 2019), and have not been integrated with advances that provide qualitative means to define impacts on human wellbeing (Bacher et al. 2017). Together this has reduced incentives for policy makers to respond to biological invasions, owing to a lack of monetary 
quantifications of invasive species impacts, despite methodological advances for quantifying benefits of invader management in economic terms (Bacher et al. 2018, Hanley and Roberts 2019).

Invasive alien species (IAS) can impact economies in both conspicuous and inconspicuous ways. Particularly, impacts from invasions can encompass resource damages and losses (Paini et al. 2016), proactive and reactive spending on various forms of management to prevent, control and eradicate invaders (Robertson et al. 2020), and less direct environmental impacts that adversely affect, for example, tourism and recreational activities (Hanley and Roberts 2019). For management interventions, expenditure in preventative biosecurity measures for invasions can be more cost efficient than longer term management (Leung et al. 2002; Ahmed et al. 2021), and can help to negate future damages. However, most national economies, i.e. the scale at which policy decisions are made, have no centralized, systematic or comprehensive means of reporting, nor collating, economic costs of biological invasions (Diagne et al. 2020). For example, means of identifying taxonomic groups that are most damaging, habitat types most impacted, and sectors most affected could help in efficiently directing allocations of resources (Cuthbert et al, 2021a, b). Previous highly-cited works on the economic impacts in the United States (Pimentel et al. 2001, 2005) and Europe (Kettunen et al. 2009) brought valid attention to the burgeoning economic impacts of invasions, but they have come under scrutiny (e.g. Cuthbert et al. 2020) given unclear methodologies, such as the inability to distinguish which costs were empirically observed, and a reliance on sometimes extreme extrapolations from small, localised scales.

New Zealand is widely regarded as a country at the forefront of IAS management (Hayden and Whyte 2003, Russell et al. 2015, Simberloff 2019). This country was one of the last land masses on Earth to be colonised by humans and, as an isolated archipelago, was, and is, typically vulnerable to the severe impacts of introduced species (Allen \& Lee 2006). Together, this meant early natural historians, and subsequently wildlife managers, simultaneously saw the impacts and costs of IAS, but also the benefits that could be gained from their successful management (Bellingham et al 2010, Towns et al. 2013, Bell et al 2016, Bell 2016). This also meant, from relatively early on, New Zealand had a strong degree of biosecurity to prevent unwanted introductions, originally with a focus on agricultural protectionism, but later expanded to include biodiversity protection (Hayden and Whyte 2003). New Zealand has strict IAS screening protocols based on a rigorous evidence-based assessment of the risks associated with a given overseas port or on particular goods (Hulme 2020, Robinson et al. 2020). While expensive, these protocols are implemented with the intention of avoiding greater future costs associated with established IAS management and damages (Leung et al., 2002; Ahmed et al., 2021). This is in contrast to the vast majority of countries globally where a blacklisting approach (i.e. only specifically named species are banned), and a greater reliance on individual responsibility to declare biological material, is typical. New Zealand has also led the world in pioneering the eradication of IAS - including established mammal species from small islands (Towns et al. 2013), incursions of arthropods on the large inhabited islands (Brockerhoff et al. 2010) and the eradication of non-native plants (Hulme 2020). One particular feature of New Zealand - the only remote archipelago that is a developed nation independent of any continental authority - positions this country well to be a world leader in IAS management (Simberloff 2019). However, despite its successes and place at the forefront on the global stage, the country still suffers 
from invasion debts (i.e. the time-delay before an already introduced species becomes invasive; Sheppard et al. 2016, Brandt et al. 2020) and incursions of new known IAS that pose substantial ongoing challenges to management.

The first global compilation of reported invasion costs ('InvaCost') has recently been published (Diagne et al. 2020, 2021), providing the most comprehensive, synthesised database of IAS economic impacts to date. It also provides a standardized living platform for the reporting, comparison and synthesis of invasion costs in the future, enabling continuous updating by scientists, managers and stakeholders (Diagne et al. 2020, 2021). While limitations remain, as awareness and uptake of this resource increases, it will be invaluable to invasive species research. For example, a lack of easily accessible damage costs can impede efficient allocation of targeted management across species or habitats (Ahmed et al 2021). Using data available from the InvaCost database, we summarised and described reported economic costs of invasions in New Zealand across approximately the last fifty years. Assessments of IAS in New Zealand already exist, but are typically small-scale, being limited to specific economic sectors or taxonomic groups (Hackwell \& Bertram 1999, Barlow \& Goldson 2002, Allen \& Lee 2006, Nimmo-Bell et al 2009, Clout et al 2011, Saunders et al. 2013, Ferguson et al. 2019). Here, we investigated how the currently available reported costs of invasions are characterized across all (a) environments, (b) cost types, (c) economic sectors and (d) taxonomic groupings. We also examined the temporal trends in the costs of both damage to resources and management investment, where we predict an increase in damage costs through time given the ongoing increase in biological invasions worldwide (Seebens et al 2017), but accompanied with a significant increase in management costs as a result of New Zealand's broadly proactive approach to managing IAS impacts (Towns et al. 2013, Simberloff 2019). We interpret these results within the specific context of New Zealand, and more broadly to the reported economic costs of invasions in other countries and regions internationally.

\section{Methods}

\section{Data collection}

To describe the cost of invasions in New Zealand, we used cost data collected in the latest available version of the InvaCost database (v4.0), as of June 2021 (Diagne et al. 2020; Angulo et al. 2021; data openly available at https://doi.org/10.6084/m9.figshare.12668570). Full details on the process of the literature search are provided elsewhere (Diagne et al. 2020). Briefly, three online bibliographic sources (ISI Web of Science, Google Scholar, and the Google search engine) were examined using a series of carefully composed search strings, creating standardised searches within the peer-reviewed and grey literature for the economic costs of IAS. Such costs could be presented at any taxonomic level, spatial scale or time period and to any economic sector. All cost entries were standardized to a common and upto-date currency (2017 US\$), although here we also report them as 2017 NZ\$ (US\$ $\times 1.4$ as of 1 Jan 2017) for national context. The official market exchange rates were obtained from the World Bank Open Data and adjusted using an inflation factor that accounted for the changes in US\$ since the cost estimation year using consumer price indices (Diagne et al., 2020). Using the "Official_country" column within the 
database, we filtered entries for New Zealand, including all reported costs from 1960 - 2020 to ensure accurate cost standardisation and the latest year from which costs have been collected respectively ( $n=2$ pre-date this point [1883 and 1945]). We report results as both cost values and number of reports. We note that the searches made to compile the database may under-represent groups such as microbes (e.g. pathogenic bacteria or viruses) because, although their spread can be dramatically enhanced by invasive hosts, they are frequently not defined by authors as invasive species in their own right (Vilcinskas 2015, Roy et al 2017). The subset of the database used for New Zealand is provided as Supplementary Material 1.

\section{Estimating total costs}

Deriving the cumulative cost of invasions over time requires consideration of the duration of each cost occurrence. We calculated this cost duration as the number of years between the database columns "Probable_starting_year_adjusted" and "Probable_ending_year_adjusted". In a few instances, costs were omitted ( $n=12)$ because they had unclear durations because either the start, end or both years were not specified in the original source. We opted to remove these entries to avoid biases when assessing temporal dynamics of costs (i.e. with costs specified over too few or many years). To calculate the total cumulative cost, we first standardised all the cost entries on an annual basis for their defined period of occurrence. Hence, for example, a single cost entry recorded as occurring over a six-year period was transformed to six cost entries, with the total cost divided to get an annual cost that was repeated for each of the six entries. Our dataset therefore initially consisted of 810 annualized cost entries from 124 unique references.

Invasion costs were then considered and estimated according to six descriptive columns present in the database (see Diagne et al. 2020 and https://doi.org/10.6084/m9.figshare.12668570 for complete details on these descriptors):

(i) "Method_reliability": a conservative but objective evaluation of the traceability of the cost estimation ("High" vs "Low"). This is based on the type of publication and method of estimation i.e. peer-reviewed or other official documents from the grey literature are likely validated prior to publication so are classified as "High" reliability. Other materials were only classified as "High" if the original sources, assumptions and methods were accessible and fully described.

(ii) "Implementation": referring to whether the cost estimate was actually realised in the invaded habitat ("Observed") or whether it was extrapolated ("Potential").

(iii) "Environment_IAS": whether the cost was incurred from biota that are either "Aquatic", "Terrestrial" or "Diverse/Unspecified" (i.e. either unspecified or a combination of species and hence biomes).

(iv) "Type_of_cost_merged": collation of costs according to principal categories: (a) "Damage", referring to damages or losses incurred by invasion (e.g. costs for damage repair, resource losses); (b) "Management", comprising management-related expenditure (e.g. monitoring, prevention, control, 
eradication); and (c) "Mixed" costs, including a mixture of damage and management costs. We also used the "Management_type" column to compare management expenditure between pre- and post-invasion actions. Here, pre-invasion management comprised monetary investments for preventing successful invasions in an area including quarantine or border inspection, risk analyses, biosecurity management etc.; and post-invasion management includes money spent on managing invaded areas, and so includes control, eradication or containment. Additional categories comprised: (a) "knowledge/funding" - money allocated to any action or operation that could be relevant to management at pre- or post-invasion stages, but is not specifically attributed within the source e.g. administration, communication, education or research costs; (b) "mixed" - costs that included at least (and without possibility to disentangle the specific proportion of) two of the previous categories; and (c) "unspecified" - costs where the exact nature was not clearly defined.

(v) "Impacted_sector": the activity, societal or market sector that was impacted by the cost (e.g."Agriculture", "Health" or "Authorities and Stakeholders" - this latter category representing official structures and organisations allocating efforts to manage IAS). Individual cost entries not allocated to a single sector were classified as "Mixed", and records without an identifiable sector, or those that were unreported, were classified as "Unspecified". These are relatively broad groupings as the level of granularity provided within references varied substantially. Importantly, there was very rarely sufficient detail to attribute costs to, for example, specific stakeholders, communities or specific health impacts, even if these were mentioned, rather than to the collective sector groupings detailed above.

(vi) Species: the taxonomic nomenclature of the species causing the cost.

We focussed the majority of our analyses on a conservative approach to the reported costs, retaining only those which were graded as both observed (i.e. had actually occurred) and having 'high' reliability (i.e. a level of peer review or method reproducibility), hereafter called 'robust' costs

To analyse the economic costs of invasive species over time, we used the summarizeCosts function in the R package "invacost" (Leroy et al., 2020). With this function, we calculated (i) the average annual costs over the entire 1960-2020 period (in 2017 US\$), and (ii) the total costs per decade. This temporal analysis was performed separately for management and damage costs. The InvaCost database includes data covering a range of spatial scales from site-specific to national level. We considered all scales in our analysis as there is no reason to expect that cost amounts and spatial scales show a linear relationship (e.g. some impacted items may be very expensive despite small impacted areas, others may benefit from economies of scale), but carefully checked the data for duplicates across scales, e.g. the same specieslocation pair reported twice. Identified duplicates were eliminated. We did not extrapolate cost estimates from smaller to larger scales, and such extrapolations are only included in InvaCost if the underlying cost documents did so and explicitly described their estimation methods (see "Implementation" above). In many cases, a lack of extrapolation could render our results underestimates, but we stress that InvaCost is a compilation of reported costs from underlying studies, that extrapolations can come from either 
"High" or "Low" reliability sources (see below), and that such extrapolations from smaller scales have been previously recognised as potentially problematic (Cuthbert et al. 2020).

Finally, we used log-log linear regressions to examine the relationship between Gross Domestic Product (GDP, World Bank 2019) and total (a) pre-invasion management (b) post-invasion management and (c) damage costs for New Zealand, as well as for all other countries represented in the InvaCost database (using the same filtering system to include only highly reliable, observed costs between 1960 and 2020 with specified temporal durations in each case). We use these relationships to highlight differences in New Zealand's expenditure in comparison to global trends, relative to economic output.

\section{Results}

From the InvaCost database we obtained 124 unique cost records encompassing a minimum of 52 species (a number of entries did not define specific species in their assessments, see Table $\mathrm{S} 1$ for a full list) that corresponded to 810 annualised cost entries between 1968 -2020, summing to a total reported value over this period of US\$69.09 billion (NZ\$96.73 billion). Over half of the cost entries $(n=453)$ were directly observed from actual costs, with the remainder being predicted, potential costs. Of the directly observed cost entries, over four fifths ( $n=368$ ) were classed as highly reliable, with a total figure for these highly reliable, observed costs of US\$8.83 billion (NZ\$12.36 billion, Figure 1). The following analyses focus only on these highly reliable, observed costs, hereafter called 'robust' costs.

For these robust costs of biological invasions, approximately one third of the total cost (36\%), and most annualised entries (62\%), occurred within the terrestrial environment (Figure 1, Table S2). Cost entries were common from the aquatic environment (29\%), but with a very low proportion of the total recorded cost $(1 \%)$, with the remainder from diverse/unspecified environments ( $9 \%$ of entries but $62 \%$ of cost, Figure 1, Table S2). The majority of recorded cost entries (65\%) were associated with management; damage cost entries represented a much smaller proportion (35\%), but management investments were far smaller than damage cost (18\% vs. 82\%) (Figure 1). The greatest proportion of the robust cost total was borne by the primary industries of agriculture and forestry ( $47 \%$ combined), and this sum represented $27 \%$ of the annualised entries. Other significant proportions of the robust cost total were borne by unspecified sectors (36\%) - although this reflected a very small number of annualised entries $(<1 \%)-$ and Authorities and Stakeholders (16\% of total cost but $50 \%$ of entries). There was very limited total cost reported from the health, public and social welfare and environment sectors (all < $1 \%$ ) (Figure 1, Table S3). The majority of cost entries were caused by animals ( $88 \% ; 15 \%$ of cost), then plants $(8 \% ; 31 \%$ of cost) and chromists $(2 \% ;<1 \%$ of cost); diverse or unspecified groups contributed the remainder of entries and the majority of the total cost.

Estimates of annual management costs since the 1960 s averaged at US\$26.16 milion while damage costs were an order of magnitude higher at US\$120.41 million; management costs were first reported a decade later than damages (Figure 2). Despite undulations in recent decades, management and damage costs both tended to increase through time, with management costs peaking at US\$122.72 million per 
annum in the 2000s, and damage costs peaking at US\$488.40 million in the 2010s. However, damage costs were consistently greater than management costs within each decade (Figure 2). In general, numbers of costs reported increased over time considering the robust data (Figure 2). Across all environments, management costs have most consistently been spent on control, although expenditure on other management types has increased by one order of magnitude in the most recent decade (Figure 3), with eradications representing the greatest total spend (Table S4). As a result, post-invasion management spending (US\$1.41 billion) massively exceeded pre-invasion management (US\$0.07 billion) (Table S4).

Robust costs included information on a minimum of 52 IAS, with those reported as incurring the greatest damage costs (>US\$200 million) being agricultural weeds (e.g. creeping thistle [Cirsium arvense], yellow foxtail [Setaria pumila], giant buttercup [Ranunculus acris]) and pest arthropods (e.g. Argentine stem weevil [Listronotus bonariensis]). Introduced species reported as incurring the greatest management costs (>US\$50 million) were also associated with primary industries, but were a different group of species that included the established pest animal brushtail possum (Trichosurus vulpecula) and the Varroa mite (Varroa destructor). Noteworthy management costs included those to eradicate invading pest arthropods prior to their spread (e.g. painted apple moth [Teia anartoides], red imported fire ant [Solenopsis invicta] and gypsy moth [Lymantria dispar]) and eradications of established pest mammals on isolated islands (e.g. feral cats [Felis catus] and European rabbits [Oryctolagus cuniculus]) (see Table S1 for a full list of specific species costs).

Invasion costs related significantly positively to GDP considering damage $(t=5.688, p<0.001)$ and postinvasion management $(t=6.549, p<0.001)$, but not pre-invasion management $(t=1.604, p=0.123)$, at the global scale. In terms of these global economic cost patterns, reported costs across both management types are relatively high in New Zealand, and higher than would be predicted based on GDP (Figures 4, S1); although this likely reflects study effort to some extent and not solely economic impact. Based on the global pattern among the 20 countries reporting both management types, post-invasion and pre-invasion management in New Zealand were both about 5 times higher than expected based on GDP. However, globally, pre-invasion spending is less frequently reported overall (Figures 4, S1).

\section{Discussion}

Our results provide robust evidence that biological invasions incur substantial and increasing economic costs through diverse negative impacts to socio-ecosystems, although reported costs are not evenly distributed across taxa or sectors in New Zealand. Costs have reached at least US\$8.8 billion (NZ\$12.4 billion) over the last 50 years based on only the most robust estimates, with most costs thus far resulting from damage caused by terrestrial IAS, and rapidly increasing over time. Despite New Zealand's welldeserved reputation as a world leader in addressing IAS from a variety of pre-and post-invasion perspectives, this situation where damage costs are growing and substantially exceed management investments is similar to many other countries and regions (e.g. Bradshaw et al 2021, Haubrock et al. 2021) and confirms our hypothesis. Previously, it has been estimated that IAS are regularly associated with over NZ\$1 billion a year of losses in New Zealand (Godson et al. 2015) corresponding to over 1\% of 
the national GDP (Nimmo-Bell 2009). We show here that reported economic costs, which are conservative estimates given that robust values are not present for all species (Bradshaw et al. 2016; Hoffmann and Broadhurst 2016; Diagne et al. 2020), are approaching this value, and inclusion of other values, such as predicted cost estimates, would result in this cost being exceeded over the past decade. Our comparison of robust direct economic costs across different invasive taxa and invaded ecosystems provides context to the level of economic threat biological invasions pose, and a minimum damage value to weigh against response and mitigation expenditure (Turner et al. 2004, Dasgupta 2021).

Economic costs of IAS are diverse and can be difficult to compare across spatial and temporal scales or different implementation methods (observed empirically, extrapolated from small-scale study, modelled as predictions etc.). However, by utilising descriptors within the InvaCost database we were able to account for and compare across this broad diversity and complexity of heterogeneous reported cost estimates. Damage costs made up the principal economic burden and were mostly reported from terrestrial primary industries, which dominate New Zealand's economy (NZ\$38.1 billion export value in 2017; MPI 2017), and where such costs are most easily estimated through financial losses. Management costs also focused, in part, on remediating this damage to terrestrial primary industries. However, this spend focussed not just on introduced species currently incurring large damage costs, but also on preventative measures where upfront investment in management would prevent large future damage costs being incurred. While reported post-invasion management expenditure overwhelmingly predominated over pre-invasion expenditure, costs associated with the latter, for example in terms of biosecurity staff salaries, facility costs, research grant breakdowns etc., are rarely within the public domain, for example as a result of privacy legislation, and thus are unlikely to be captured within this database. This makes a completely accurate comparison between proactive biosecurity management undertaken at early invasion stages and post-invasion control and eradication management challenging due to data deficiencies. However, New Zealand now invests a relatively high amount in IAS prevention activities such as pathway management border controls, and is a world leader in pre-border pest risk management (Brenton-Rule et al. 2016, Hulme 2020). These prevention activities aim to prevent IAS arriving, and often apply to multiple species simultaneously, so they are anticipated to be a more costeffective way of achieving the same benefits as management activities further along the invasion spectrum (Leung et al 2002, Ahmed et al 2021). However, empirical tests of this comparison are complex and ethically challenging, requiring a robust design applying multiple management approaches (pre- vs. post-invasion at a minimum) to the same invader and ecosystem across comparable time periods. Nevertheless, due to a long history of, and ongoing dependency on, primary production, and more recently tourism, New Zealand continues to emphasise a proactive approach to biosecurity, which has benefits for multiple industries (Jay et al. 2003, Brockerhoff et al. 2010).

As well as a focus on mitigating economic damage to industry, substantial investment in New Zealand has also been made in managing IAS threats to biodiversity, particularly the initially high up-front investment in complete eradication, with its anticipated longer-term reduction in economic or ecological costs. This can be seen in the significant proportion of post-management expenditure on this approach, and it has become common for introduced mammals on uninhabited offshore and "mainland islands" of 
New Zealand (Clout and Russell 2006), and has now been proposed nationally (Russell et al. 2015, Bell 2016). Such eradications for biodiversity protection have also been extended to arthropods (Brown et al. 2019, Green et al 2019). Managing threats to biodiversity often occurs despite a lack of detailed information on the economic impacts of such actions and, indeed, many benefits associated with biodiversity and healthy ecosystems are not easily quantified monetarily. Importantly, this skew towards species which cause impacts that are readily monetized implicitly biases cost reporting against those which primarily impact native biodiversity and ecosystem functioning. Accordingly, the costs detailed here are both conservative as a whole, but likely most conservative when considering species with predominantly ecological impacts. While non-market impacts are increasingly acknowledged, there remain issues surrounding either the lack of, or the correct method of assessment for, associated monetary costs. Furthermore, some impacts, for example spiritual costs, are arguably impossible to value purely economically, although approaches such as revealed preferences can be used to apply values to these known impacts (Shackleton 2019a,b). Importantly, despite debate around attributing economic costs, the loss of ecosystem services e.g. carbon sequestration, recreation or culturally significant sites, can play a key role in the justification of IAS management (Holmes et al., 2009; Hanley and Roberts, 2019).

Regardless of the types of impact, management of biological invasions require additional economic spending (Clout 2011). However, in New Zealand, decadal means for reported management costs (including all costs identified under control, eradication, biosecurity and research/communication categories) have been exceeded by decadal means for reported damage costs for the past forty years. This is also true across the majority of recent years (Figure 2), with a potentially worrying increase in the gap between management spend and damage incurred in the most recent decade (although this is necessarily caveated by incomplete reporting for the most recent years given inevitable publication lags $($ mean $=6$ years $)$ ). This situation is reflected in many parts of the world where economic losses from damage far outstrip management costs (Crystal-Ornelas et al. 2021, Diagne et al., 2021, Haubrock et al. 2021, Liu et al. 2021). Although the overall management spend in New Zealand does not appear sufficient to maintain pace with reported damages, the specific focus of investment into protecting taonga (biodiversity and heritage assets), often extremely successfully (Allen and Lee 2006, Bellingham 2010, Towns et al. 2013), with their less readily monetised benefits may also explain some of this difference. This approach may even increase in the coming decades with the PredatorFree2050 program (Bell et al 2016), although this has clear long-term objectives to reduce both management and damage related expenditure. Indeed, when disentangling pre-invasion from post-invasion management in New Zealand, proportional spending on early stage management was considerably higher than in many other countries within the InvaCost database when considering their economic output. This stresses the relative scale of funding allocation to early stage investments in New Zealand, which have undoubtedly reduced the burden of current and future IAS costs, but highlights that there remains the potential for further gains. .

In addition to differential reporting of ecological costs, there are other costs of biological invasions missing from the database for a range of reasons. There are undoubtedly true gaps in reported damage 
costs, and consequent lack of, or limited, investment in management. These include introduced game animals e.g. chamois Rupicapra rupicapra and common pheasant Phasisanus colchicus and freshwater fish such as trout Salmo trutta, which engender conflict through opposing values on whether they are pests (thereby incurring a damage cost) or resources (thereby not requiring control and, indeed, providing economic benefits) (Russell 2014). This conflict likely results in absences of spending on management, combined with controversy and a reluctance to attribute damage costs, although they do still controversially occur (Hughey and Hickling 2006). Economic assessments are similarly lacking or speculative for many parasites and diseases as a result of debate over their description as IAS in their own right, their cryptogenic nature, and a generally poor understanding of their epidemiology or virulence prior to emergence (Fisher et al 2012, Gross et al 2014, Vilcinskas 2015, Roy et al 2017). This is true even for those that damage commercially-important species, for example Bonamia ostreae which can adversely affect oysters Ostrea chilensis (Lane et al. 2016). Reported harm to human health was also low, and is likely underestimated (Wilson et al. 2017); although this may still reflect an actual low level of impact from biological invasions on human health in New Zealand. Lastly, species such as clover root weevil (Sitona lepidus), pea weevil (Bruchus pisorum) and termites (Order Isoptera) have had large amounts spent on them by the Ministry of Primary Industries and Biosecurity New Zealand, but this information remains in internal reports and spreadsheets that never leave the organisation (S. Wood, pers comms August 31, 2020). This level of difficulty in accessing relevant data, and the inability of searches to locate such information without the need to specifically target key, potentially unknown, individuals, represents a major barrier to obtaining accurate pictures of the economic impacts of IAS. Therefore, parties that collect these data, including central government, regional agencies and scientists, should also prioritize their publication such that their availability and impact are maximized, facilitating, for example, independent advice to governments or the linking of environmental management to broader concepts of wellbeing.

While New Zealand currently engages in annual national environmental reporting (Ministry for the Environment \& Stats NZ 2019), a comprehensive framework for collecting and reporting the damages and management costs of introduced species does not yet exist (Nimmo-Bell 2009); although New Zealand is no different to other countries in this respect. Further efforts to quantify and produce openly available invasion costs for specific species, regions and sectors would enable a more holistic and granular account of the diversity and scale of IAS impacts. This current incompleteness often prevents accurate total estimates for e.g. specific invasive species costs. That such gaps in knowledge or data availability exist in a country acknowledged to lead the world in its approach to IAS (Simberloff 2019), further highlights the need for improved efforts across countries globally to increase reporting in order to raise this issue in the public consciousness, to inform on the effective deployment of resources, and to produce meaningful policy changes. Improving the quality of reported data, for example providing clear information on timeframes of expenditure, and greater detail on cost breakdowns (i.e. specific species, techniques, locations and which stakeholders invested and benefitted from expenditure for each cost), would facilitate syntheses and comparative assessments and refine funding strategies at multiple levels. 
Emerging threats in biological invasions, and a wider acknowledgement that costs are simultaneously incurred, and borne by, multiple sectors, has led to greater cross-agency partnership in the management of biological invasions in New Zealand (Jay et al. 2003). However, managing such multi-party responses brings additional complexity with respect to ensuring sufficient resource allocation and effective inclusion of cultural values and viewpoints, particularly when significant expenditure is at stake ( $\mathrm{Ngā}$ Rākau Taketake 2021). It also has the potential to further complicate open, accessible reporting of costs if lines of responsibility are unclear. A current ongoing example of multi-agency operations, given the invasion process is identical and responsive to the same attitudes and policies as unwanted organism management, is New Zealand's early eradication and rigorous biosecurity approach to SARS-CoV-2 (Nuñez et al., 2020). Given the ongoing potential for invasive species to facilitate emerging infectious diseases, such proactive and integrated approaches would be highly beneficial (Hulme 2014, Roy et al. 2017, Ogden et al. 2019). Total eradication of unwanted organisms has the potential to contribute widely to all aspects of society and its sustainable development (de Wit et al. 2020) and this view is readily accepted in New Zealand, where eradication of invasive species is regularly pursued whenever technically possible and economically reasonable (Department of Conservation 2021).

The information contained in the unique source of cost data analysed here provides a basis for helping to guide and encourage open reporting practice to facilitate research, management and active steps to address the socio-economic impacts of IAS in New Zealand and beyond. We again stress that knowledge gaps and inaccessibility of potentially incurred costs make the costs reported here substantial underestimates. Nonetheless, as a centralised platform for standardized cost reporting, we encourage researchers and organisations to submit their data to the InvaCost database to enhance the comprehensiveness of future cost appraisals as biological invasions, their impacts and mitigation measures ensue. This will ensure a more complete understanding of economic costs and benefits under different strategies, a critical requirement for successful prevention and management of biological invasions.

\section{References}

Ahmed, D.A., Hudgins, E.J., Cuthbert, R.N., Kourantidou, M., Diagne, C., Haubrock, P.J., Leung, B., Liu, C., Leroy, B., Petrovskii, S., Courchamp, F., 2021. Biol. Invasions DOI 10.21203/rs.3.rs-300416/v1

Allen, R.B., Lee, W.G. 2006. Biological Invasions in New Zealand. Springer, Heidelberg.

Angulo, E., Diagne, C., Ballesteros-Mejía, L., Akulov, E.N., Dia, C.A.K.M., Adamjy, T., et al., 2021. Non-English languages enrich scientific data: the example of the costs of biological invasions. Science of the Total Environment.

Anton, A., Geraldi, N.G., Ricciard, A., Dick, J.T.A. 2020. Global determinants of prey naiveté to exotic predators. Proc Roy Soc B: Biol Sci, 287, 20192978. 
Bacher, S., Blackburn, T.M., Essl, F., Genovesi, P., Heikkila J., Jeschke, J.M., et al. 2018. Socio-economic impact classification of alien taxa (SEICAT). Meth Ecol Evol 9:159-168

Barlow, N.D. \& Goldson, S. 2011. Alien invertebrates in New Zealand. In: Pimentel D (Ed)

Biological invasions: economic and environmental costs of alien, plant, animal,

and microbe species. CRC Press, Boca Raton, 195-216.

Bell, E., Bell, B.D., Merton, D.V. 2016. The legacy of Big South Cape: Rat irruption to rat

eradication. NZ J Ecol 40: 212-218.

Bell, M. 2016. Accelerating predator free New Zealand. New Zealand Government, Wellington, NZ.

Bellard, C., Genovesi, P., Jeschke, J. 2016. Global patterns in threats to vertebrates by

biological invasions. Proc Roy Soc B: Biol Sci 283: 20152454.

doi:https://doi.org/10.1098/rspb.2015.2454

Bellard, C., Rysman, J-F., Leroy, B., Claud, C., Mace, G.M. 2017. A global picture of biological invasion threat on islands. Nature Ecol Evol 1: 1862-1869 doi:10.1038/s41559-017-0365-6

Bellingham, P.J., Towns, D.R., Cameron, E.K., Davis, J.J., Wardle, D.A., Wilmshurst, J.M., Mulder, C.P. 2010. New Zealand island restoration: seabirds, predators, and the importance of history. NZ J Ecol 34(1):115.

Bradshaw, C.J.A., Leroy, B., Bellard, C., Roiz, D., Albert, C., Fournier, A., et al., 2016. Massive yet grossly underestimated global costs of invasive insects. Nature Comms 7: 12986.

doi:https://doi.org/10.1038/ncomms12986

Bradshaw, C.J.A., Haubrock, P.J., Cuthbert, R.N., Diagne, C., Leroy, B., Andrews, L., et al., 2021, Comprehensive assessment of the economic costs of invasive species in Australia. NeoBiota.

Brandt, A.J., Bellingham, P.J., Duncan, R.P., Etherington, T.R., Fridley, J.D., Howell, C.J., et al., 2020. Naturalised plants transform the composition and function of New Zealand flora. Biol Invasions 23: 351366.

Brenton-Rule, E., Frankel, S., \& Lester, P. 2016. Improving management of invasive species:

New Zealand's approach to pre-and post-border pests. Policy Quarterly, 12(1).

doi:https://doi.org/10.26686/pq.v12i1.4582

Brockerhoff, E.G., Liebhold, A.M., Richardson, B., Suckling, D.M. 2010. Eradication of invasive forest insects: concepts, methods, costs and benefits. NZ J Forestry Sci 40: S117-S135 
Brown, K., Phillips, C., Broome, K., Green, C., Toft, R., Walker, G. 2019. Feasibility of eradicating the large white butterfly (Pieris brassicae) from New Zealand: data gathering to inform decisions about the feasibility of eradication. In: Veitch C, Clout M, Martin A, Russell J, West C (Eds) Island invasives: scaling up to meet the challenge.

IUCN, Gland, Switzerland, 364-369. doi:https://doi.org/10.2305/IUCN.CH.2019.SSC-OP.62.en

Clout, M. 2011. Ecological and economic costs of alien vertebrates in New Zealand. In: Pimentel D (Ed) Biological invasions: economic and environmental costs of alien, plant, animal, and microbe species. CRC Press, Boca Raton, 283-291.

Clout, M., Russell, J. 2006. The eradication of mammals from New Zealand islands. In: Koike F, Clout M, Kawamichi M, De Poorter M, Iwatsuki K (Eds) Assessment and Control of Biological Invasion Risks. IUCN, Gland, Switzerland, 127-141

Courchamp, F., Pascal, M., Chapuis, J-L. 2003. Mammal invaders on islands, impact, control and control impact. Biol Rev. 78: 347-383.

Crystal-Ornelas, R., Lockwood, J.L. 2020. The 'known unknowns' of invasive species impact measurement. Biol invasions 22: 1513-1525. doi:https://doi.org/10.1007/s10530-020-02200-0

Crystal-Ornelas, R., Hudgins, E., Cuthbert, R.N., Haubrock, P.J., Fantle-Lepczyk, J., Angulo, E., et al., 2021. Economic costs of biological invasions within North America. Neobiota

Cuthbert, R.N., Bacher, S., Blackburn, T.M., Briski, E., Diagne, C., Dick, J.T.A., et al., 2020. Invasion costs, impacts, and human agency: Response to Sagoff 2020. Conservation Biology, 34: 1579-1582.

Cuthbert, R.N., Pattison, Z., Taylor, N.G., Verbrugge, L., Diagne, C., Ahmed, D.A., et al., (2021a) Global economic costs of aquatic invasive alien species. Science of the Total Environment, 775:145238.

Cuthbert, R.N., Diagne, C., Haubrock, P.J., Turbelin, A.J., Courchamp, F. 2021b Are the "100 of the world's worst" invasive species also the costliest? Biol Invasions, in press.

Dasgupta, P. 2021. The Economics of Biodiversity: The Dasgupta Review. (London: HM Treasury)

Department of Conservation, 2021. Technical feasibility study report for eradication of pigs, mice and cats from Auckland Island. Department of Conservation Te Papa Atawhai, Invercargill, New Zealand, 123 p.

de Wit, L.A., Zilliacus, K.M., Quadri, P., Will, D., Grima, N., Spatz, D., et al., 2020. Invasive vertebrate eradications on islands as a tool for implementing global Sustainable Development Goals. Environ Cons 47: 139-148. doi:https://doi.org/10.1017/S0376892920000211 
Diagne, C., Leroy, B., Gozlan, R.E., Vaissière, A.C., Assailly, C., Nuninger, L., et al., 2020. InvaCost, a public database of the economic costs of biological invasions worldwide. Sci Data 7: 277.

doi:https://doi.org/10.1038/s41597-020-00586-z

Diagne, C., Leroy, B., Vaissière, A.C. et al. 2021. High and rising economic costs of

biological invasions worldwide. Nature https://doi.org/10.1038/s41586-021-03405-6

Diagne, C., Turbelin, A., Moodley, D., Novoa, A., Leroy, B., Angulo, E., et al, 2021. The economic costs of biological invasions in Africa: a growing but neglected threat? Neobiota

Dick, J.T.A., Laverty, C., Lennonm J.J., Barrios-O'Neill, D., Mensink, P.J., Britton, R.J., et al., 2017. Invader Relative Impact Potential: a new metric to understand and predict the ecological impacts of existing, emerging and future invasive alien species. J Appl Ecol 54: 1259-1267.

doi: https://doi.org/10.1111/1365-2664.12849

Early, R., Bradley, B.A., Dukes, J.S., Lawler, J.J., Olden, J.D., Blumenthal, D.M., et al., 2016. Global threats from invasive alien species in the twenty-first century and national response capacities. Nature Comms 7: 12485. doi:https://doi.org/10.1038/ncomms12485

Essl, F., Lenzner, B., Bacher, S., Bailey, S., Capinha, C., Daehler, C., et al., 2020. Drivers of future alien species impacts: An expert-based assessment. Global Change Biol 26: 4880-4893.

doi:https://doi.org/10.1111/gcb.15199

Ferguson, C.M., Barratt, B.I.P., Bell, N., Goldson, S.L., Hardwick, S., Jackson, M., et al., 2019. Quantifying the economic cost of invertebrate pests to New Zealand's pastoral industry. NZ J Agri Res 62: 255315 https://doi.org/10.1080/00288233.2018.1478860

Fisher, M.C., Henk D.A., Briggs, C.J., Brownstein, J.S., Madoff, L.C., McCraw, S.L., Gurr, S.J. 2012. Emerging fungal threats to animal, plant and ecosystem health. Nature 484:186-194

Fournier, A., Penone, C., Pennino, M.G., Courchamp, F. 2019. Predicting future invaders and future invasions. PNAS 116: 7905-7910. doi:https://doi.org/10.1073/pnas.1803456116

Godson, S.L., Bourdôt, G.W., Brockerhoff, E.G., Byrom, A.E., Clout, M.N., McGlone, M.S., et al., 2015. New Zealand pest management: current and future challenges. J Roy Soc NZ 45: 31-58.

doi:https://doi.org/10.1080/03036758.2014.1000343

Green, C.J. 2019. Effort required to confirm eradication of an Argentine ant invasion: Tiritiri Matangi Island, New Zealand. In: Veitch C, Clout M, Martin A, Russell J, West C (Eds) Island invasives: scaling up to meet the challenge. IUCN, Gland, Switzerland, 364-369.

Gross, A., Holdenrieder, O., Pautasso, M., Queloz, V., Sieber, T.N.2014. Hymenoscyphus pseudoalbidus, the causal agent of European ash dieback. Mol Plant Path 15:5-21

Page $15 / 24$ 
Hackwell, K., Bertram, G. 1999. Pests and weeds: the cost of restoring an indigenous dawn chorus: a blueprint for action against the impacts of introduced pest organisms on the New Zealand environment. New Zealand Conservation Authority, Wellington, NZ

Hanley, N., Roberts, M. 2019. The economic benefits of invasive species management. People and Nature 1: 124-137. doi:https://doi.org/10.1002/pan3.31

Haubrock, P.J., Turbelin, A.J., Cuthbert, R.N., Novoa, A., Angulo, E., Ballesteros-Mejia, L., et al., 2021. Economic costs of invasive alien species across Europe. NeoBiota.

Hayden, B.J., Whyte, C.F. 2003. Invasive species management in New Zealand. In: Ruiz GM, Carlton JT (Eds) Invasive species: vectors and management strategies. Island Press, Washington, DC, 270-291

Hughey, K.F., Hickling, G.J. 2006. Ecologically based policy evaluation: application to ungulate management in New Zealand. Environ Sci and Policy 9: 639-651. doi:https://doi.org/10.1016/j.envsci.2006.07.001

Holmes, T.P., Aukema, J.E., Von Holle, B., Liebhold, A., Sills, E. 2009. Economic impacts of invasive species in forests: past, present, and future. Ann N Y Acad Sci, 1162, 18-38. doi:10.1111/j.1749$6632.2009 .04446 . x$

Hulme, P.E. 2009. Trade, transport and trouble: managing invasive species pathways in an era of globalization. J Appl Ecol 46: 10-18. doi: https://doi.org/10.1111/j.1365-2664.2008.01600.x

Hulme, P.E. 2014. Invasive species challenge the global response to emerging diseases. Trends in Parasitology 30: 267-270.

Hulme, P.E. 2020. Plant invasions in New Zealand: global lessons in prevention, eradication and control. Biol Invasions 22: 1539-1562.

Hoffmann, B.D., Broadhurst, L.M. 2016. The economic cost of managing invasive species in Australia. NeoBiota, 31, 1.

Jay, M., Morad, M., Bell, A. 2003. Biosecurity, a policy dilemma for New Zealand. Land Use Policy 20:121129. doi:https://doi.org/10.1016/S0264-8377(03)00008-5

Kettunen, M., Genovesi, P., Gollasch, S., Pagad, S., Starfinger, U., ten Brink, P., Shine, C. 2009. Technical support to EU strategy on invasive alien species (IAS). Institute for European Environmental Policy (IEEP), Brussels, Belgium, $44 \mathrm{pp}$.

Lane, H.S., Webb, S.C., Duncan, J. 2016. Bonamia ostreae in the New Zealand oyster Ostrea chilensis: a new host and geographic record for this haplosporidian parasite. Diseases of Aqua Organisms 118: 55- 
Leroy, B., Kramer, A., Vaissière, A-C., Courchamp, F., Diagne, C. 2020. Analysing global economic costs of invasive alien species with the invacost $\mathrm{R}$ package. bioRxiv doi: https://doi.org/10.1101/2020.12.10.419432

Leung, B., Lodge, D.M., Finnoff, D., Shogren, J.F., Lewis, M.A., Lamberti, G. 2002. An ounce of prevention or a pound of cure: bioeconomic risk analysis of invasive species. Proc Roy Soc B: Biol Sci 269: 2407-2413. doi:https://doi.org/10.1098/rspb.2002.2179

Liu, C., Diagne, C., Angulo, E., Banerjee, A.K., Chen, Y., Cuthbert, R.N., et al., 2021. Economic costs of biological invasions in Asia. Neobiota.

Ministry for the Environment \& Stats NZ, 2019. New Zealand's Environmental Reporting Series:Environment Aotearoa 2019. Ministry for the Environment and Stats NZ, 128 pp.

Ngā Rākau Taketake - Saving our Iconic Trees, 2021. National Science Challenges, New Zealand. https://bioheritage.nz/research/saving-our-iconic-trees/ Accessed 16/04/21.

Nimmo-Bell, 2009. Economic Costs of Pests to New Zealand. MAF Biosecurity New Zealand Technical Paper No: 2009/31, 79 pp.

Nuñez, M.A., Pauchard, A., Ricciardi, A. 2020. Invasion Science and the Global Spread of SARS-CoV-2. Trends Ecol Evol 35: 642-645. doi:https://doi.org/10.1016/j.tree.2020.05.004

Ogden, N.H., Wilson, J.R.U., Richardson, D.M., Hui, C., Davies, S.J., Kumschick, S., et al., 2019. Emerging infectious diseases and biological invasions: a call for a One Health collaboration in science and management. Roy Soc Open Sci 6 doi:https://doi.org/10.1098/rsos.181577

Paini, D.R., Sheppard, A.W., Cook, D.C., De Barro, P.J., Worner, S.P., Thomas, M.B. 2016. Global threat to agriculture from invasive species. PNAS 201602205. doi:https://doi.org/10.1073/pnas.1602205113

Pimentel, D., McNair, S., Janecka, J., Wightman, J., Simmonds, C., O'Connell, C., et al., 2001 Economic and environmental threats of alien plant, animal, and microbe invasions. Agri Ecosystems Environ 84: 1-20. doi:https://doi.org/10.1016/S0167-8809(00)00178-X

Pimentel, D., Zuniga, R., Morrison, D. 2005. Update on the environmental and economic costs associated with alien-invasive species in the United States. Ecol Econ 52: 273-288. doi:https://doi.org/10.1016/j.ecolecon.2004.10.002

Robertson, P.A., Mill, A., Novoa, A., Jeschke, J.M., Essl, F., Gallardo, B., et al., 2020. A proposed unified framework to describe the management of biological invasions. Biol invasions 22: 2633-2645. doi:https://doi.org/10.1007/s10530-020-02298-2 
Robinson, A., Welsh, M., Ormsby, M., Brockerhoff, E., Reed, C. 2020. Proportional value of

interventions across pathways and layers of New Zealand's biosecurity system. Peer-Reveiwed Technical Report 16006E, CEBRA.

Roy, H.E., Hesketh, H., Purse, B.V., Eilenberg, J., Santini, A., Scalera, R., 2017. Alien pathogens on the horizon: opportunities for predicting their threat to wildlife. Cons Letts 10: 477484. https://doi.org/10.1111/conl.12297

Russell, J.C. 2014. A comparison of attitudes towards introduced wildlife in New Zealand in 1994 and 2012. J Roy Soc NZ 44: 136-151. https://doi.org/10.1080/03036758.2014.944192

Russell, J.C., Innes, J.G., Brown, P.H., Byrom, A.E. 2015. Predator-Free New Zealand: Conservation Country. Bioscience 65: 520-525. doi:10.1093/biosci/biv012

Russell, J.C., Meyer, J-Y., Holmes, N.D., Pagad, S. 2017. Invasive alien species on islands: impacts, distribution, interactions and management. Environ Cons 44:359-370. doi:https://doi.org/10.1017/S0376892917000297

Saunders, J.T., Saunders, C.M., Buwalda, J.G., Gerard, P.J., Bourdôt, G.W., Wratten, S.D., Goldson, S.L. 2013. The economic impact of failures in plant protection to New Zealand. PeerJ PrePrints 1:e140v1 https://doi.org/10.7287/peerj.preprints.140v1

Seebens, H., Blackburn, T.M., Dyer, E.E., Genovesi, P., Hulme, P.E., Jeschke, J.M., et al.,2017. No saturation in the accumulation of alien species worldwide. Nature Comms 8: 14435. doi:https://doi.org/10.1038/ncomms14435

Seebens, H., Bacher, S., Blackburn, T.M., Capinha, C., Dawson, W., Dullinger, S., et al., 2020 Projecting the continental accumulation of alien species through to 2050. Global Change Biol.

doi:https://doi.org/10.1111/gcb.15333

Shackleton, R.T., Richardson, D.M., Shackleton, C.M., Bennett, B., Crowley, S.L., Dehnen-Schmutz, K., et al., 2019a. Explaining people's perceptions of invasive alien species: a conceptual framework. J Environ Manag 229:10-26.

Shackleton, R.T., Shackleton, C.M., Kull, C.A. 2019b. The role of invasive alien species in shaping local livelihoods and human well-being: A review. J Environ Manag 229:145-157.

Sheppard, C.S., Burns, B.R., Stanley, M.C. 2016. Future-proofing weed management for the effects of climate change: is New Zealand underestimating the risk of increased plant invasions? NZ J Ecol 40 : 398-405

Simberloff, D., Martin, J-L., Genovesi, P., Maris, V., Wardle, D.A., Aronson, J., et al., 2013. Impacts of biological invasions: what's what and the way forward. Trends Ecol Evol 28: 58-66. 
Simberloff, D. 2019. New Zealand as a leader in conservation practice and invasion management. J Roy Soc NZ 49: 259-280. doi:https://doi.org/10.1080/03036758.2019.1652193

Towns, D.R., West, C., Broome, K. 2013. Purposes, outcomes and challenges of eradicating invasive mammals from New Zealand islands: an historical perspective. Wildl Res 40: 94. doi:https://doi.org/10.1071/WR12064

Turner, J., Bulman, L., Richardson, B., Moore, J. 2004. Cost-benefit analysis of biosecurity and forest health research. NZ J Forestry Sci 34: 324-343

Vilcinskas, A. 2015. Pathogens as biological weapons of invasive species. PLoS Pathog 11(4): e1004714. https://doi.org/10.1371/journal.ppat.1004714

Wilson, N., McIntyre, M., Blaschke, P., Muellner, P., Mansoor, O.D., Baker, M.G. 2017. Potential public health benefits from eradicating rats in New Zealand cities and a tentative research agenda. J Roy Soc NZ 48:280-290.

\section{Declarations}

Competing interests: The authors declare no competing interests

\section{Figures}




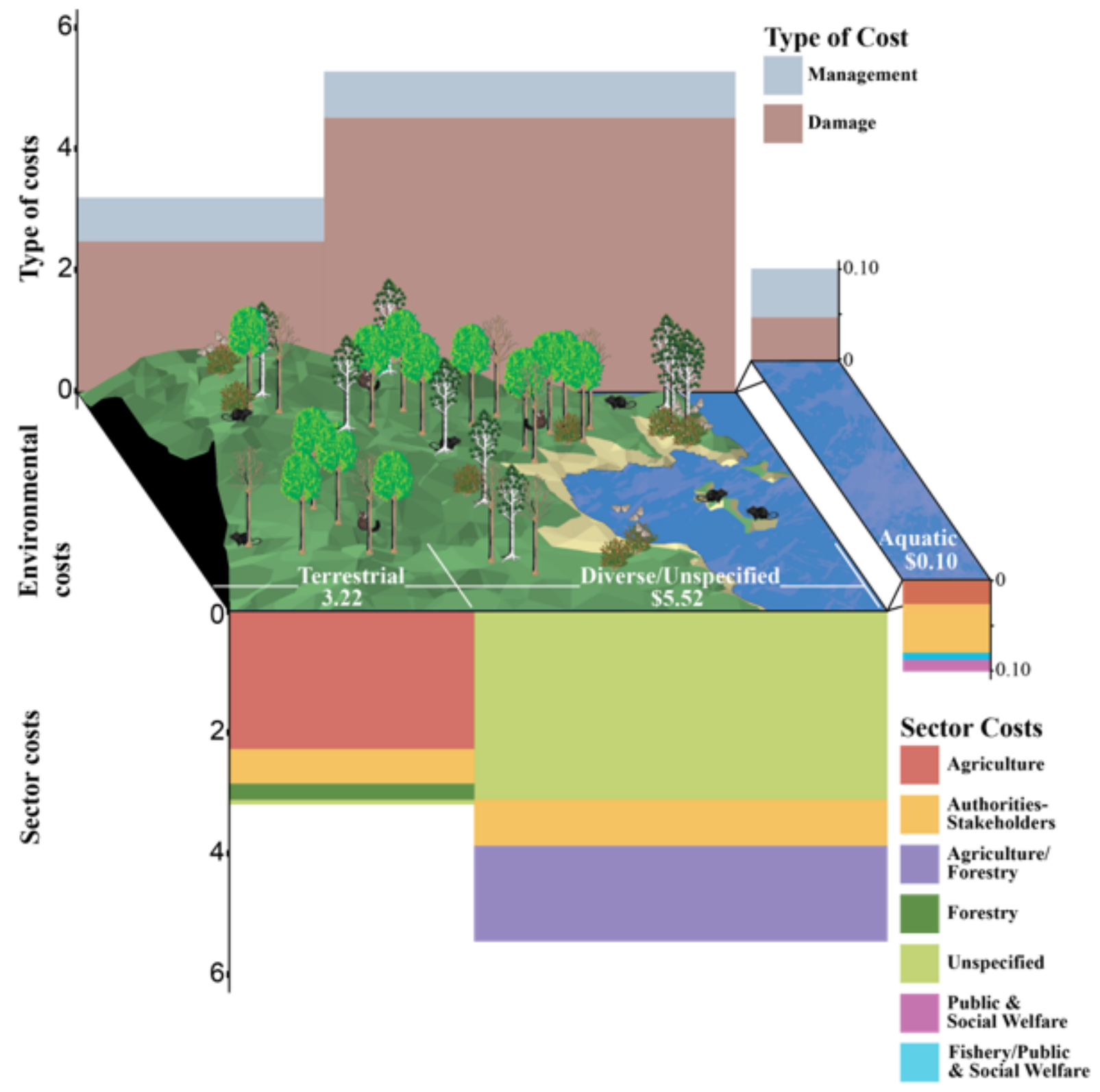

\section{Figure 1}

The economic cost of biological invasions in New Zealand from 1960 to 2020 from the InvaCost v4.0 database using only robust costs. Costs are totalled according to the environmental type in which they occurred and, within each environment, by the socioeconomic sectors impacted and the type of costs (management or damage) incurred. Only sectors with costs greater than US\$50 000 are presented for clarity. Widths for type and sector costs are scaled relative to their environmental cost contributions. All costs are shown in US\$ billions. 


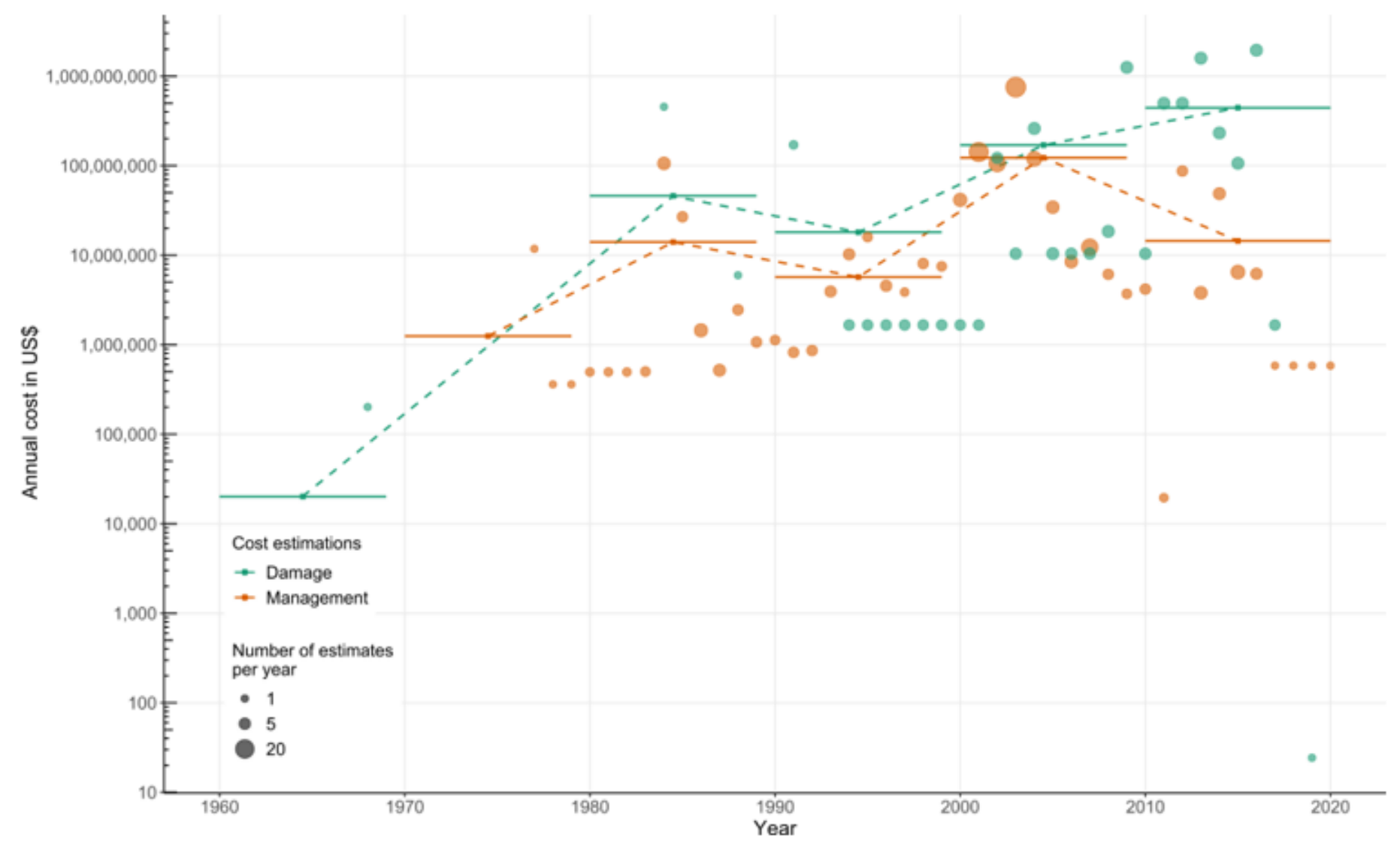

Figure 2

Temporal development of management and damage costs of biological invasions in New Zealand from the InvaCost database (v4.0) using only robust costs. Each respective orange and green dot represents the annual reported costs for management and damage (no dot means an absence of reported costs for that year). Solid horizontal bars and squares indicate decadal averages of economic costs (management - orange, damage - green), with fine dashed lines linking the decadal means. 

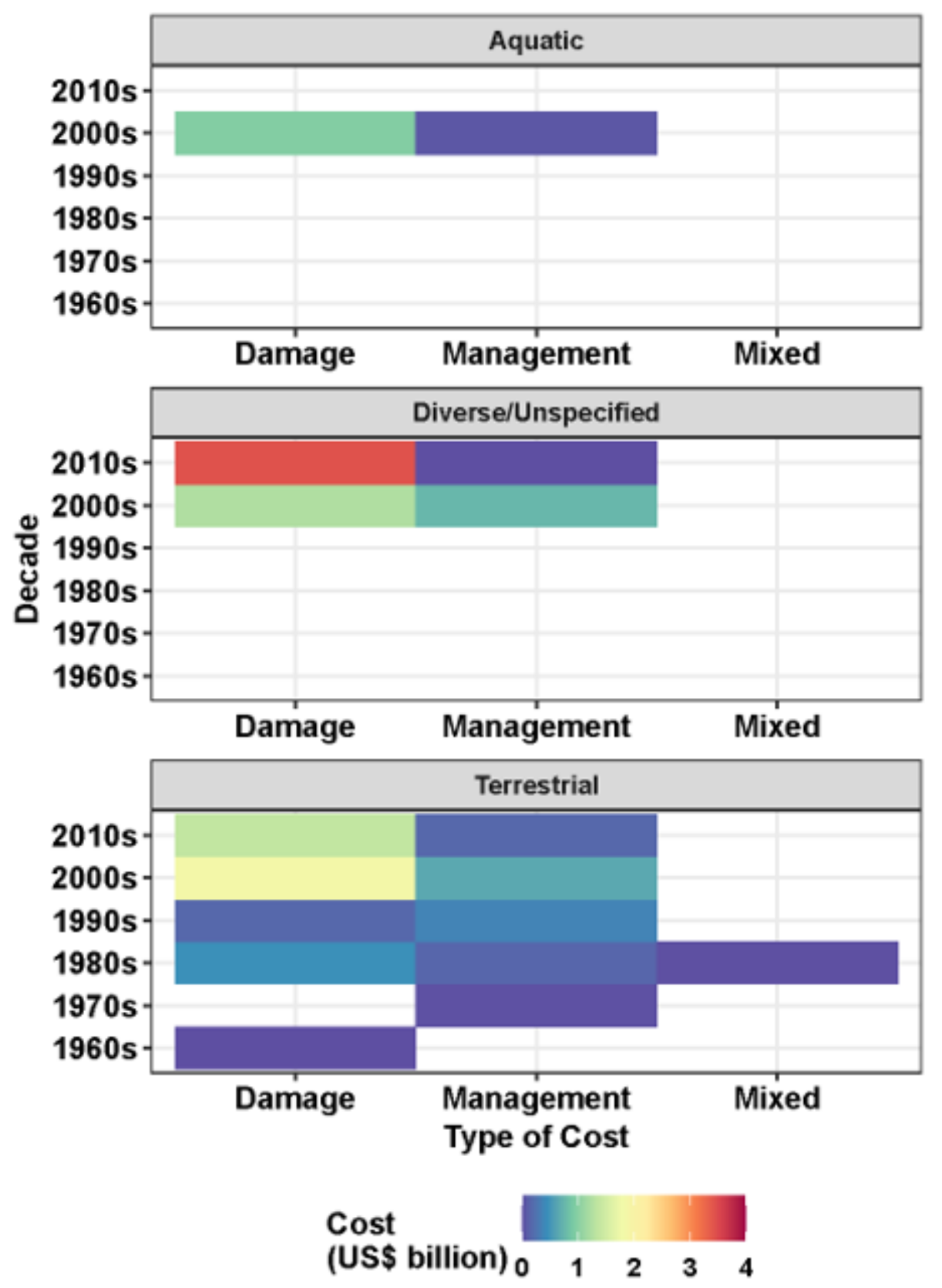

Figure 3

Heatmap demonstrating the magnitude of costs (US\$ billions) of IAS in New Zealand as a function of management cost type per decade across differing environments. 


\section{Reported management expenditures}

\section{(relatively to GDP)}

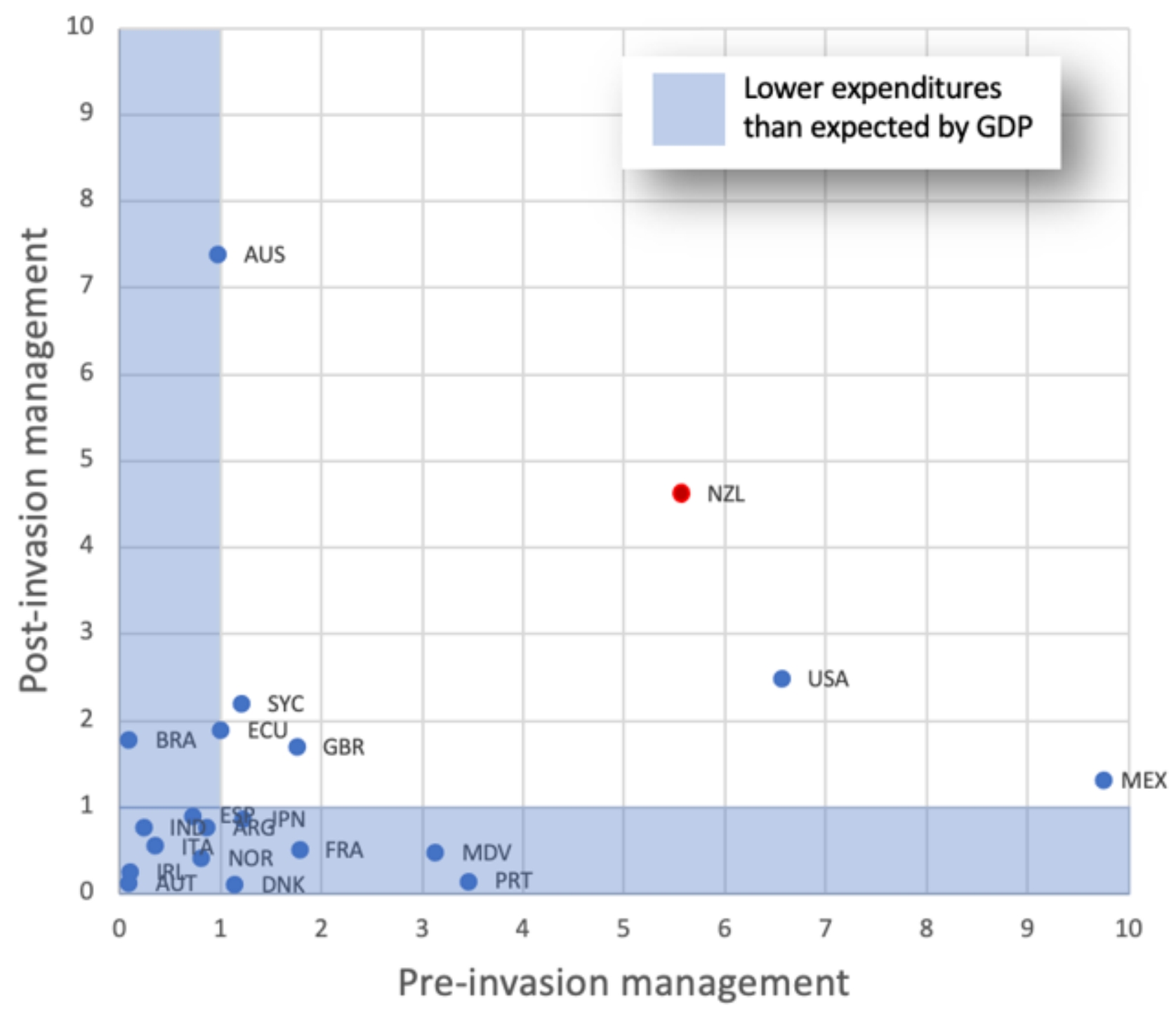

Figure 4

Management expenditures related to expectations from correlation with GDP for all countries within the InvaCost database where pre- and post-invasion management approaches are recorded. Each point represents the ratio of observed over expected expenditures within a country for pre-invasion management ( $x$ axis) and post-invasion management ( $y$ axis). The area shaded blue contains all countries with lower than expected expenditures $($ ratio $<1)$ for either pre- or post-invasion management. New Zealand (red dot) spends significantly more than expected from its GDP on both pre- and postinvasion management costs.

\section{Supplementary Files}


This is a list of supplementary files associated with this preprint. Click to download.

- NZCostofBiologicallnvasionsSupplementResearchSquare.docx 